\title{
A Fluorescent Probe for the Specific Staining of Cysteine Containing Proteins and Thioredoxin Reductase in SDS-PAGE
}

\author{
Yuning Liu ${ }^{1,2}$, Yanan Yu ${ }^{1,2}$, Qingshi Meng 1,2, Xueting Jia ${ }^{1,2}$, Jiawei Zhu ${ }^{1,2}$, Chaohua Tang ${ }^{1,2}$, Qingyu Zhao ${ }^{1,2}$, \\ Xiaohui Feng $1,2, *$ and Junmin Zhang $1,2, * \mathbb{D}$ \\ 1 State Key Laboratory of Animal Nutrition, Institute of Animal Science, Chinese Academy of Agricultural \\ Sciences, Beijing 100193, China; liuyuning001@126.com (Y.L.); yuyanan@caas.cn (Y.Y.); \\ mengqingshi@caas.cn (Q.M.); jiaxueting2018@163.com (X.J.); zhujiaweisemail@163.com (J.Z.); \\ tangchaohua@caas.cn (C.T.); zhaoqingyu@sina.com (Q.Z.) \\ 2 Scientific Observing and Experiment Station of Animal Genetic Resources and Nutrition in North China of \\ Ministry of Agriculture and Rural Affairs, Institute of Animal Science, Chinese Academy of Agricultural \\ Sciences, Beijing 100193, China \\ * Correspondence: fengxiaohui@caas.cn (X.F.); zhjmxms@sina.com (J.Z.)
}

Citation: Liu, Y.; Yu, Y.; Meng, Q.; Jia, X.; Zhu, J.; Tang, C.; Zhao, Q.; Feng, X.; Zhang, J. A Fluorescent Probe for the Specific Staining of Cysteine Containing Proteins and Thioredoxin Reductase in SDS-PAGE. Biosensors 2021, 11, 132. https:// doi.org/10.3390/bios11050132

Received: 18 March 2021

Accepted: 21 April 2021

Published: 23 April 2021

Publisher's Note: MDPI stays neutral with regard to jurisdictional claims in published maps and institutional affiliations.

Copyright: (c) 2021 by the authors. Licensee MDPI, Basel, Switzerland. This article is an open access article distributed under the terms and conditions of the Creative Commons Attribution (CC BY) license (https:// creativecommons.org/licenses/by/ $4.0 /)$.

\begin{abstract}
A naphthalimide-based fluorescent probe, Nap-I, with iodoacetamide as the alkylating group, has been synthesized, and its specific fluorescent staining of proteins containing cysteine (Cys) and selenocysteine (Sec) residues in sodium dodecyl sulfate polyacrylamide gel electrophoresis (SDS-PAGE) has been evaluated. This molecule shows good fluorescence properties in the labeling of protein Cys/Sec residues, while reducing steric hindrance and minimizing changes in the water solubility of proteins. Reaction parameters, such as labeling time and $\mathrm{pH}$, have been investigated, and the optimal labeling conditions for Cys-containing proteins have been determined. Thioredoxin reductase (TXNRD) is best stained at low $\mathrm{pH}$. The probe Nap-I has been successfully used for the quantification of serum proteins and hemoglobin in Tan sheep serum, and TXNRD in Tan sheep liver and muscle has been labeled at low $\mathrm{pH}$. Based on the probe Nap-I, we have also distinguished TXNRD1 and TXNRD2 by SDS-PAGE. The results showed that, compared with the normal microenvironment in which the protein resides, the lower the $\mathrm{pH}$ value, the greater the TXNRD activity.
\end{abstract}

Keywords: fluorescent probe; thiol; thioredoxin reductase; SDS-PAGE; labeling; low pH; iodoacetamide; naphthalimide

\section{Introduction}

Sulfur and selenium are elements of the same group, and their chemical properties have many similarities. At the same time, sulfur and selenium are also indispensable elements in living organisms. As an important part of amino acids and antioxidant substances in the body, many biomolecules incorporate thiol and selenol moieties, including selenoproteins and some small molecules, such as glutathione (GSH), cysteine (Cys), selenocysteine (Sec), hydrogen selenide $\left(\mathrm{H}_{2} \mathrm{Se}\right)$, and so on [1]. Thiols and selenols have strong reducing properties and show very similar biological functions. Both Se in selenols and $S$ in thiols can adopt multiple oxidation forms from -2 to +4 , endowing them with versatile reactivity [2]. Thus, selenol and thiols with redox activity are important substances that maintain the stability of the redox state of the microenvironment and buffer important redox changes to regulate cell function and body balance. They provide disease diagnosis and treatment options by participating in some physiological processes and redox reactions. Cells maintain their redox balance based on a well-developed regulatory system. The subhealth state of cells often leads to an increase in reactive oxygen species (ROS) and a change in $\mathrm{pH}$ [3]. Selenols with relatively low $\mathrm{p} K_{\mathrm{a}}$ values are more likely to be deprotonated, enabling the reduction of some ROS, thereby serving as anti-oxidants [4,5]. Although the 
abundance of selenols in organisms is much lower than that of thiols, their extremely strong reducing properties make them the first line of defense in protecting cells from oxidation. Inhibition of thioredoxin reductase (TXNRD, TrxR) can seriously affect the function of the thioredoxin system in cells and cause cell death. Therefore, targeting the TXNRD in cancer cells is a very effective cancer treatment measure [6-8]. Selenols and thiols with abnormal levels can lead to poor health, weakened immunity, and various diseases, such as muscle diseases, diabetes, cardiovascular diseases, and neurodegenerative diseases [9]. Since selenols are more easily oxidized than thiols, the monitoring and detection of selenols is more challenging. At the same time, selenols are more active at low $\mathrm{pH}$, which provides a good means of detecting them in tissue samples in vitro [10,11].

Most of the selenol-specific fluorescent probes are adapted versions of thiol-specific probes, such as 2,4-dinitrophenyl [12-14], disulfide bond compounds [15-18], gold-sulfur bonds [19,20], Michael acceptors [21-23], benzoselenodiazole [24-27], and so on [9,28-32]. In fact, the first probe used to detect selenols was adapted from a thiol probe at low $\mathrm{pH}[11,33]$. The $\mathrm{p} K_{\mathrm{a}}$ of selenol is generally low, for Sec is 5.2, but for Cys is 8.5. Since the deprotonation ability of thiols is weakened at low $\mathrm{pH}$, and the deprotonation ability of selenols is enhanced, fluorescent probes with the same detection group may respond better to selenols in a shorter time or at lower $\mathrm{pH}$ values. Maleimide [34,35], methyl sulfate [36], and alkyl halides [37] are all good thiol alkylating reagents. As a common thiol alkylation reagent, iodoacetamide (IAA) has become the first choice for labeling thiol-containing proteins and improving the detection signal of trace thiols [38,39]. Indeed, new thiollabeling fluorescent probes with iodoacetamide as a functional group are constantly being developed. The rapid development of "click chemistry" has also expedited the use of iodoacetamide fluorescent probes [10]. The alkylation efficiency of alkyl halides for thiols decreases at low $\mathrm{pH}$, but the alkylation efficiency for selenols increases. In fact, by using iodoacetamide fluorescent probes to alkylate selenol groups in selenoproteins at low $\mathrm{pH}$, the detection of more selenoproteins can be achieved [10,40,41].

Fluorescent labeling of proteins is a very important method in biochemical detection. In sodium dodecyl sulfate polyacrylamide gel electrophoresis (SDS-PAGE), protein samples are covalently or non-covalently labeled with fluorescent dyes, which can then be used to track and quantify proteins in biological processes. Compared with staining after electrophoresis, prestaining protein samples with covalent labels before electrophoresis will shorten the staining process. Dye-labeled protein typically have a good limit of detection (LOD) and signal-to-noise ratio, and such labeling can be used as a pre-staining method for protein analysis in gels [35,37]. Therefore, our aim was to systematically explore the characteristics of iodoacetamide fluorescent probes suitable for labeling thiols or selenols in different environments, and to provide a convenient and highly selective analytical method.

In this work, we have constructed a fluorescent probe for the detection of proteins containing thiol or selenol moieties. We appended iodoacetamide to naphthimide, thereby constructing a fluorescent probe, Nap-I, for labeling Cys/Sec residues in proteins. We have thoroughly studied the protein-specific staining of Cys residues with Nap-I, and have applied this labeling strategy to the determination of serum albumin and hemoglobin in the serum of Tan sheep. At the same time, Nap-I has been used to specifically stain and distinguish different TXNRDs at low $\mathrm{pH}$, and the TXNRDs in the liver and longissimus thoracis muscles of Se-enriched Tan sheep have been specifically stained.

\section{Experimental Section}

\subsection{Materials and Instrumentation}

All chemical reagents and solvents were purchased from commercial sources (SigmaAldrich and Macklin Inc) and were used without further purification. ${ }^{1} \mathrm{H}$ and ${ }^{13} \mathrm{C}$ NMR spectra were recorded on a Bruker Avance II $300 \mathrm{MHz}$ spectrometer, and chemical shifts are expressed in parts per million (ppm, with respect to DMSO and $\mathrm{Me}_{4} \mathrm{Si}$ as internal standards). Mass spectrum was performed on a Sciex triple TOF 6600 set-up. Absorp- 
tion spectra were recorded on a Metash UV-8000A ultraviolet-visible spectrophotometer. Fluorescence spectra and quantum yields were measured at room temperature on an FS5 spectrofluorimeter (Edinburgh Instruments). Samples for absorption and fluorescence measurements were placed in a $1 \mathrm{~cm} \times 1 \mathrm{~cm}$ quartz cuvette $(1 \mathrm{~mL}$ volume). Gel fluorescence imaging was performed with a Gel Doc XR+ documentation system (Bio-Rad). Images were analyzed with Quantity One gel image analysis software (Bio-Rad). The enzyme activity of TXNRD in Tan sheep liver and muscle was measured by a commercial kit method [oxidized thioredoxin reductase (TrxR) test kit from Nanjing Jiancheng Bioengineering Institute].

\subsection{Synthesis of Nap-I}

Nap-I was synthesized following the procedure shown in Scheme 1. A mixture of compound $3(0.389 \mathrm{~g}, 1 \mathrm{mM})$ and sodium iodide $(1.5 \mathrm{~g}, 10 \mathrm{mM})$ in dry acetone $(20 \mathrm{~mL})$ was stirred in a flask and heated under reflux for $24 \mathrm{~h}$ in the dark under $\mathrm{N}_{2}$ protection. After natural cooling, the mixture was filtered and the filtrate was collected. The solvent was evaporated under reduced pressure and the residue was dried and separated by chromatography on a silica gel column $\left(\mathrm{V}_{\mathrm{DCM}} / \mathrm{V}_{\mathrm{MeOH}}=10: 1\right)$ to afford Nap-I $(0.45 \mathrm{~g}$, yield: 93\%). ${ }^{1} \mathrm{H}$ NMR (300 MHz, DMSO- $\left.d_{6}\right): \delta 8.64(\mathrm{~d}, J=8.4 \mathrm{~Hz}, 1 \mathrm{H}), 8.37(\mathrm{~d}, J=7.4 \mathrm{~Hz}, 1 \mathrm{H})$, $8.20(\mathrm{~d}, J=8.5 \mathrm{~Hz}, 1 \mathrm{H}), 7.68(\mathrm{~d}, J=5.4 \mathrm{~Hz}, 1 \mathrm{H}), 7.67-7.59(\mathrm{~m}, 1 \mathrm{H}), 6.74(\mathrm{~d}, J=8.6 \mathrm{~Hz}, 1 \mathrm{H})$, 4.85-4.73 (m, 1H), $4.09(\mathrm{~d}, J=6.7 \mathrm{~Hz}, 1 \mathrm{H}), 3.63(\mathrm{~s}, 1 \mathrm{H}), 3.57(\mathrm{~d}, J=7.0 \mathrm{~Hz}, 2 \mathrm{H}), 3.38(\mathrm{~d}$, $J=6.3 \mathrm{~Hz}, 1 \mathrm{H}), 3.19(\mathrm{q}, J=6.5 \mathrm{~Hz}, 1 \mathrm{H}), 1.83 \mathrm{ppm}(\mathrm{p}, J=7.0 \mathrm{~Hz}, 1 \mathrm{H}) ;{ }^{13} \mathrm{C} \mathrm{NMR}(75 \mathrm{MHz}$, DMSO-d $\left.d_{6}\right): \delta 168.22,164.00,163.15,150.51,134.26,130.70,129.45,128.54,124.35,121.88$, $120.12,107.75,103.89,58.12,41.45,40.44,40.33,40.05,39.77,39.49,39.21,38.93,38.65,37.07$, 27.75, 1.01 ppm; HRMS (ESI): $m / z$ calcd for $\mathrm{C}_{19} \mathrm{H}_{20} \mathrm{IN}_{3} \mathrm{O}_{4}\left([M+\mathrm{H}]^{+}\right): 482.0547$; found: 482.0549 .

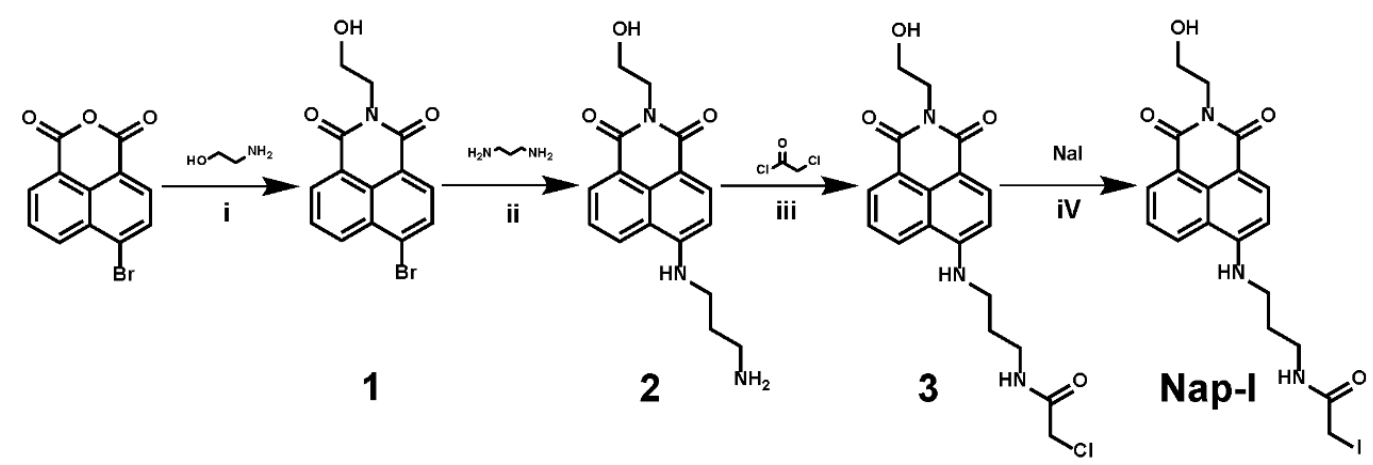

Scheme 1. Steps in the synthesis of probe Nap-I: (i) 1,4-dioxane, reflux, 4 h; (ii) 2-methoxyethanol, reflux, $3 \mathrm{~h}$; (iii) $\mathrm{CH}_{2} \mathrm{Cl}_{2}$, triethylamine, room temperature, overnight; (iv) acetone, reflux for $24 \mathrm{~h}$ in the dark.

\subsection{Fluorescence Response Measurements}

Fluorescence response of the probe Nap-I to GSH were made in Tris-HCl buffer $(100 \mathrm{mM})$ with $1 \%$ DMSO $\left(\mathrm{V}_{\text {Water }} / \mathrm{V}_{\mathrm{DMSO}}=99: 1\right)$. By excitation at $449 \mathrm{~nm}$, fluorescence spectra were recorded in the emission wavelength range of 475 to $700 \mathrm{~nm}$. The appropriate amount of probe was pre-dissolved in DMSO to prepare a $1.0 \mathrm{mM}$ Nap-I stock solution. Calibration measurements were performed by mixing different concentrations of the fluorescent probe Nap-I and GSH in $100 \mathrm{mM}$ Tris-HCl buffer. Specifically, $50.0 \mu \mathrm{L}$ of a $1 \mathrm{M}$ stock solution of GSH, $1900.0 \mu \mathrm{L}$ of Tris- $\mathrm{HCl}$ buffer solution, and $50.0 \mu \mathrm{L}$ aliquots of probe solutions of different concentrations were combined to obtain each test solution. For interference experiments, solutions of the various species to be tested $\left(\mathrm{NaCl}, \mathrm{KCl}, \mathrm{CaCl}_{2}\right.$, $\mathrm{MgCl}_{2}, \mathrm{CuSO}_{4}, \mathrm{FeCl}_{3}, \mathrm{ZnCl}_{2}, \mathrm{HCl}, \mathrm{HNO}_{3}, \mathrm{H}_{2} \mathrm{SO}_{4}$, vitamin $\mathrm{C}, \mathrm{H}_{2} \mathrm{O}_{2}, \mathrm{HClO}$, and $\left.\mathrm{NaOH}\right)$ were prepared in doubly-distilled water to give final concentrations of $100 \mu \mathrm{M}$. 


\subsection{Determination of Quantum Yield}

A solution of Nap-I in doubly-distilled water with $1 \%$ DMSO $\left(\mathrm{V}_{\text {Water }} / \mathrm{V}_{\mathrm{DMSO}}=99: 1\right)$ was prepared, and the absorbance at $553 \mathrm{~nm}$ was 0.15 . An FS5 spectrofluorimeter equipped with an SC-30 Integrating Sphere was used to characterize the absorption and photoluminescence characteristics.

\subsection{Feeding of Se-Enriched Tan Sheep}

Healthy male Tan sheep ( $n=64)$ with an average body weight (BW) of $32 \pm 1.95 \mathrm{~kg}$ were randomly assigned to one of four groups ( $n=16 /$ group). Based on a basal diet containing $0.16 \mathrm{mg} \mathrm{Se} / \mathrm{kg}$ and selenium yeast (SeY, $3300 \mathrm{mg} \mathrm{Se} / \mathrm{kg}$ ) as a selenium supplement, the four dietary treatment groups were as follows: (1) basic diet + SeY, $0.25 \mathrm{mg}$ $\mathrm{Se} / \mathrm{kg}$, (2) basic diet + SeY, $0.50 \mathrm{mg} \mathrm{Se} / \mathrm{kg}$, (3) basic diet + SeY, $1.0 \mathrm{mg} \mathrm{Se} / \mathrm{kg}$, and (4) basic diet $+\mathrm{SeY}, 2.0 \mathrm{mg} \mathrm{Se} / \mathrm{kg}$. The basal diet was formulated to meet the daily nutritional requirements for fattening sheep with a weight of $30 \mathrm{~kg}$ as described in the NY/T 816-2004 feeding standard of meat-producing sheep and goats, and met the recommended levels of the National Research Council (1985). The amount of supplemented Se in the present trial met the Se requirement of $0.18-0.31 \mathrm{mg} / \mathrm{kg}$ (maximum tolerable concentration of $2.0 \mathrm{mg} / \mathrm{kg}$ ) of the NY/T 816-2004 standard for meat-producing sheep at a BW of 20-50 kg. The Se levels of the basal diet and SeY were determined by inductively coupled plasma mass spectrometry in accordance with the Chinese national standard (GB 5009.268-2016). All sheep were provided with ad libitum access to food and water over the pre-trial period of 10 days and the experimental period of 60 days.

\subsection{Detection of Proteins}

All stained gels were imaged with the Gel Doc XR+ documentation system (Bio-Rad). The images were analyzed with Quantity One gel image analysis software (Bio-Rad). The trace quantity, which represents the intensity (int) of each pixel multiplied by the band area $\left(\mathrm{mm}^{2}\right)$, was plotted versus the amount of protein.

\subsection{Alkylation of Sec/Cys with Nap-I}

Sec, Cys (1 mM each), and a mixture of the two (1 mM each) were dissolved in $1 \mathrm{~mL}$ of buffer containing $0.1 \mathrm{~m}$ TCEP and $100 \mathrm{mM}$ Tris- $\mathrm{HCl}$ (pH 7.4), and reduced for $30 \mathrm{~min}$. The mixture was then diluted with $100 \mathrm{mM}$ Tris-HCl buffer ( $\mathrm{pH}$ 3.0-9.0), Nap-I (1 $\mu \mathrm{L})$ was added to give a final concentration of $0.1 \mathrm{mM}$, and the mixture was vortexed and briefly centrifuged. The system was incubated in the dark at room temperature for $60 \mathrm{~min}$, and then stored prior to LC-MS/MS analysis. The MS signal ratio between the alkylated form and the total intensity was used to calculate the alkylation efficiency at each $\mathrm{pH}$, and in the case of the mixture to calculate the influence of the competition of Sec and Cys in terms of alkylation efficiency at each $\mathrm{pH}$.

\section{Results and Discussion}

\subsection{Design and Synthesis of Fluorescent Probe Nap-I}

As part of our studies on iodoacetamide fluorescent probes for labeling Cys/Sec residues in proteins, we designed the new probe, Nap-I, as shown in Scheme 1. Compound 1 and Compound 2 were synthesized according to reported methods with minor changes $[42,43]$. Specifically, a naphthalimide moiety serves as the fluorophore and iodoacetamide is used as an alkylating group of Cys/Sec residues. In order to enable the fluorescent probe Nap-I to better alkylate Cys/Sec residues in proteins, we minimized the quenching effect of iodine on the fluorophore, and used 1,3-propanediamine as a linker to reduce the possible steric hindrance caused by the alkylation of Cys/Sec residues with the probe. At the same time, the appending of a hydroxyl group reduces the effect of the probe on the solubility of proteins in water. Other promising strategies for the fluorescent labeling of thiols have recently been described (Table S1) [34-39,44-46].

The new probe Nap-I was synthesized according to the route shown in Scheme 1. Com- 
mercially available 4-bromo-1,8-naphthalic anhydride was first treated with ethanolamine to produce compound 1, which was then reacted with 1,2-ethylenediamine to produce compound 2. Compound 2 was then reacted with chloroacetyl chloride to produce compound 3 , the exchange of which with sodium iodide generated probe Nap-I. The product was characterized by ${ }^{1} \mathrm{H} /{ }^{13} \mathrm{C}$ NMR spectroscopy and ESI-MS. Figures S1-S6 show the relevant spectra at each stage of the synthesis.

\subsection{Spectrophotometric Measurements of Fluorescent Probe Nap-I}

The UV/Vis and fluorescence characteristics of Nap-I were studied in $100 \mathrm{mM}$ Tris$\mathrm{HCl}$ buffer $\left(\mathrm{V}_{\text {Water }} / \mathrm{V}_{\text {DMSO }}=99: 1\right)$. As shown in Figure 1, the fluorescent probe Nap-I has an obvious absorption peak near $449 \mathrm{~nm}$. When different concentrations of Nap-I $(0-100 \mu \mathrm{M})$ were incubated with $10 \mathrm{mM}$ GSH (thiol donor), the emission wavelength was $553 \mathrm{~nm}$. As the concentration of Nap-I was increased $(0-100 \mu \mathrm{M})$, its emission intensity at $553 \mathrm{~nm}$ gradually increased, implying that alkylation of the thiol moiety on GSH by the probe does not affect its fluorescence emission (Figure 2a).

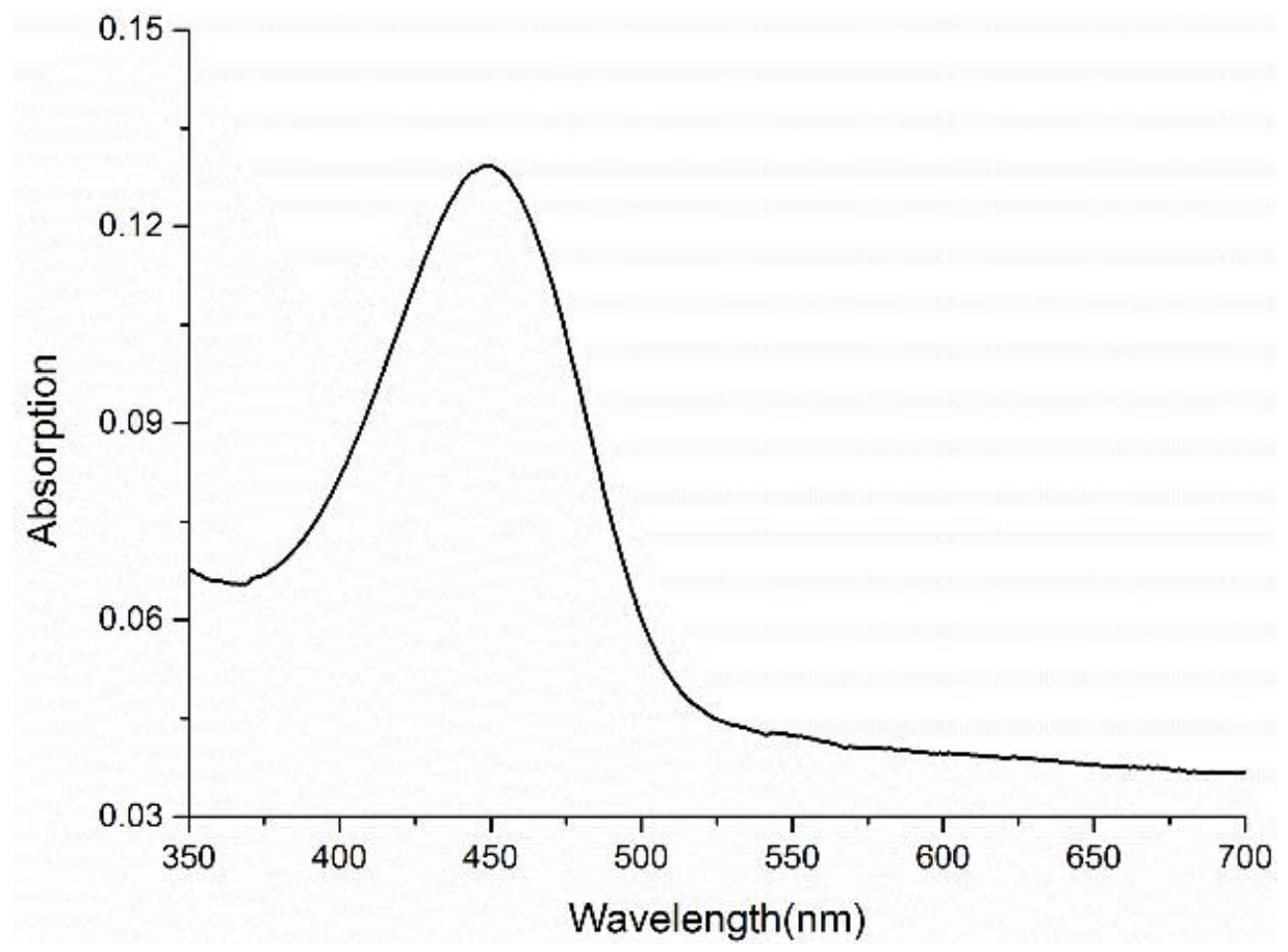

Figure 1. Absorption spectra of $100 \mu \mathrm{m}$ Nap-I in $100 \mathrm{mM}$ Tris-HCl buffer with $1 \%$ DMSO as co-solvent $\left(\mathrm{V}_{\text {Water }} / \mathrm{V}_{\mathrm{DMSO}}=99: 1\right)$.

The quantum yield was studied for $15 \mu \mathrm{M}$ Nap-I in $100 \mathrm{mM}$ Tris-HCl buffer $\left(\mathrm{V}_{\text {Water }} /\right.$ $\mathrm{V}_{\text {DMSO }}=99: 1$ ). The probe Nap-I maintains the high quantum yield of the naphthalimide fluorophore, which was calculated to be $67.7 \%$ (Figure S7).

Anti-interference ability is a key aspect for measuring new probes. Thus, to study the anti-interference ability of Nap-I, it was incubated with various cations, anions, and ROS, such as $\mathrm{NaCl}, \mathrm{KCl}, \mathrm{CaCl}_{2}, \mathrm{MgCl}_{2}, \mathrm{CuSO}_{4}, \mathrm{FeCl}_{3}, \mathrm{ZnCl}_{2}, \mathrm{HCl}, \mathrm{HNO}_{3}, \mathrm{H}_{2} \mathrm{SO}_{4}$, vitamin $\mathrm{C}$, $\mathrm{H}_{2} \mathrm{O}_{2}, \mathrm{HClO}$, and $\mathrm{NaOH}$, each at $10 \mathrm{mM}$. It can be seen from Figure S8 that when excited at $445 \mathrm{~nm}$, Nap-I gives rise to a significant increase in fluorescence intensity at $553 \mathrm{~nm}$, and that this is largely unaffected by the presence of other analytes. Next, the effect of $\mathrm{pH}$ on Nap-I and Nap-GSH was studied (Figure S9). No obvious changes in fluorescence intensity were observed in $100 \mu \mathrm{M}$ Nap-I and Nap-GSH solutions in the range pH 3.0-9.0. The results show that Nap-I can label thiols over a wide $\mathrm{pH}$ range, and that this is not affected by various species. 
Photostability is one of the important parameters of tagged fluorescent probes. We exposed Nap-GSH (100 $\mu \mathrm{M}$, Tris-HCl pH = 7.4) to a 150-W ozone-free xenon lamp for $8 \mathrm{~h}$ to test the photostability of the probe after labeling. The probe inherits the stable resonance structure of the naphthalimide fluorophore, and even after being irradiated for eight hours, the residual fluorescence intensity can reach $90 \%$ of the initial value (Figure S10).
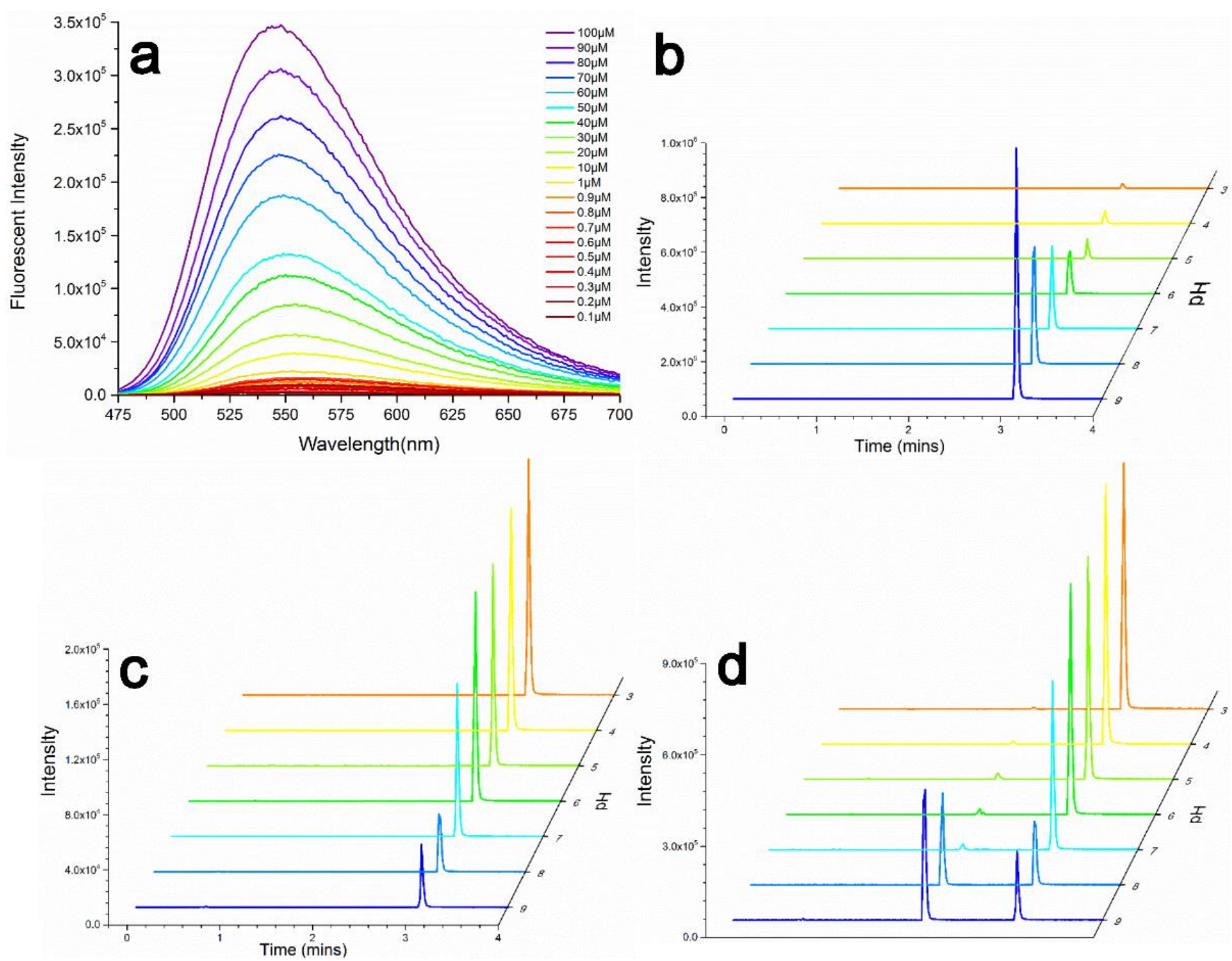

Figure 2. (a) fluorescence emission spectra of $10 \mathrm{mM} \mathrm{GSH}$ in $100 \mathrm{mM}$ Tris- $\mathrm{HCl}$ buffer with $1 \%$ DMSO as co-solvent $\left(\mathrm{V}_{\text {Water }} / \mathrm{V}_{\mathrm{DMSO}}=99: 1\right)$ at different Nap-I concentrations in the range 0-100 $\mu \mathrm{M} ;(\mathbf{b})$ alkylation efficiency of Cys by Nap-I at different $\mathrm{pH}$; (c) alkylation efficiency of Sec by Nap-I at different $\mathrm{pH}$; (d) competitive alkylation efficiencies of Cys and Sec by Nap-I.

\subsection{Alkylation Efficiency of Sec/Cys with Nap-I at Different $p H$}

The results show that Nap-I can label thiols over a wide $\mathrm{pH}$ range, and that this is not affected by various species. The alkylation efficiencies of Sec/Cys with Nap-I at different $\mathrm{pH}(3.0-9.0)$ were tested. The $\mathrm{p} K_{\mathrm{a}}$ of Cys is 8.5, and its alkylation efficiency gradually increases with increasing $\mathrm{pH}$ (Figure $2 \mathrm{~b}$ ). Conversely, the alkylation efficiency of Sec gradually increases with decreasing $\mathrm{pH}$ (Figure 2c). ESI-MS of corresponding alkylated derivatives of Nap-I to Cys/Sec are shown in Figures S5 and S6.

When Sec and Cys co-exist, as the $\mathrm{pH}$ is decreased, the competitive alkylation efficiency of Nap-I for Sec gradually increases, reaching 99.27\% at pH 3.0 (Figure 2d). In a system without Sec, Nap-I can still efficiently alkylate Cys at pH 7.0. However, in the presence of Sec, its competitive alkylation efficiency can exceed 95\% at $\mathrm{pH}<7.0$ (especially at around 
$\mathrm{pH}$ 5.2). Although the alkylation efficiency of Sec decreases at $\mathrm{pH} 3.0$, its competitive alkylation efficiency improves due to a greater decrease in the alkylation efficiency of Cys.

\subsection{Labeling of Thiol-Containing Proteins by Nap-I}

Specific labeling of Cys residues by Nap-I was examined through the labeling of proteins with different $\mathrm{Cys}$ contents. TXNRD from mouse liver (single active Cys, $54.8 \mathrm{kDa}$ TXNRD1 and 56.6 kDa for TXNRD2), bovine serum albumin (BSA) (single active Cys, $66.4 \mathrm{kDa}$ ), bovine hemoglobin (single active Cys, $64.5 \mathrm{kDa}$ ), bromelain (single active Cys, $33.0 \mathrm{kDa}$ ), papain (single active Cys, $23.4 \mathrm{kDa}$ ), and equine myoglobin (no active Cys, $17.6 \mathrm{kDa}$ ) were each labeled with $0.5 \mathrm{mM}$ Nap-I. The corresponding fluorescent products were analyzed by gel electrophoresis (Figure 3a). The proteins containing active Cys residues all showed better fluorescence intensity, but different proteins may behave slightly differently due to their enzyme activity conditions and domain exposures. TXNRD is a selenoprotein containing both thiol and selenol groups, and it also shows good fluorescence intensity. Hemoglobin in the blood is in equilibrium between dimers and tetramers, becoming a dimer after deoxygenation. 2,3-Diphosphoglyceric acid can bind to deoxyhemoglobin through salt bonds, without the involvement of disulfide bonds. This equilibrium is dependent on temperature, $\mathrm{pH}$, and anions, so its dimer only shows a band at $32 \mathrm{kDa}$ [47-49]. As shown in Figure 3b, equine myoglobin, a protein with no Cys residues in its structure and no fluorescence at $449 \mathrm{~nm}$, can be visualized by Coomassie Brilliant Blue R250 staining.

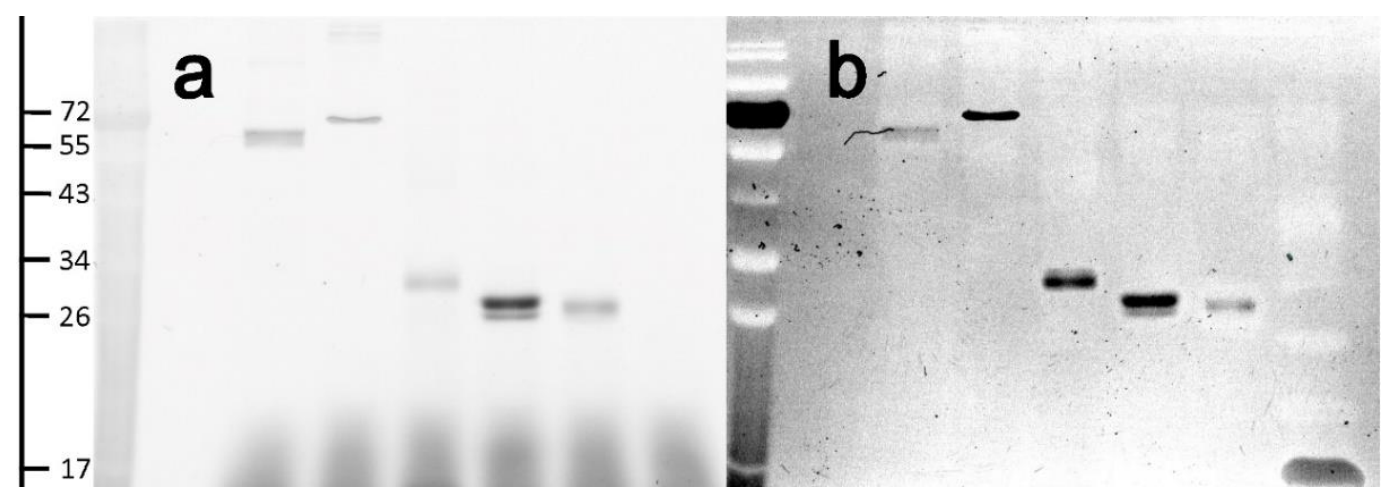

Figure 3. (a) Inverted SDS-PAGE fluorescence image of different proteins with Cys residues labeled with Nap-I; (b) image of the same gel re-stained with Coomassie R-250. Quantity of protein per band: ca. $1.5 \mu \mathrm{g}$.

We labeled BSA samples with Nap-I at room temperature for durations of 5-45 min at $\mathrm{pH}$ 7.4. The fluorescence intensity of pre-stained BSA increased with extension of the labeling time. The fluorescence of the compound reached its maximum intensity at $30 \mathrm{~min}$, and thereafter remained unchanged when the reaction time was extended for a further $15 \mathrm{~min}$ (Figure $4 \mathrm{~b}$ ). According to this result, the reaction time should be controlled at about $30 \mathrm{~min}$ to avoid any undesirable non-specific labeling. By reacting equal amounts of BSA with Nap-I in Tris- $\mathrm{HCl}$ buffer solutions at different $\mathrm{pH}$ in the range 3.0-9.0 for $30 \mathrm{~min}$, it was established that $\mathrm{pH} 8.0-9.0$ is the optimal reaction environment for a reaction time of $30 \mathrm{~min}$ (Figure 4c). Moreover, as the amount of BSA was increased from 0 to $1.5 \mu \mathrm{g}$, a good linear response was seen $\left(\mathrm{FI}=746,045 \times[\mathrm{BSA}] \mu \mathrm{g}+40,694 ; R^{2}=0.9711\right)$, and the limit of detection (LOD) was calculated to be as low as $37.5 \mathrm{nM}(2.5 \mathrm{mg} / \mathrm{L}$ ) (Figure $4 \mathrm{~d}, \mathrm{f})$. 

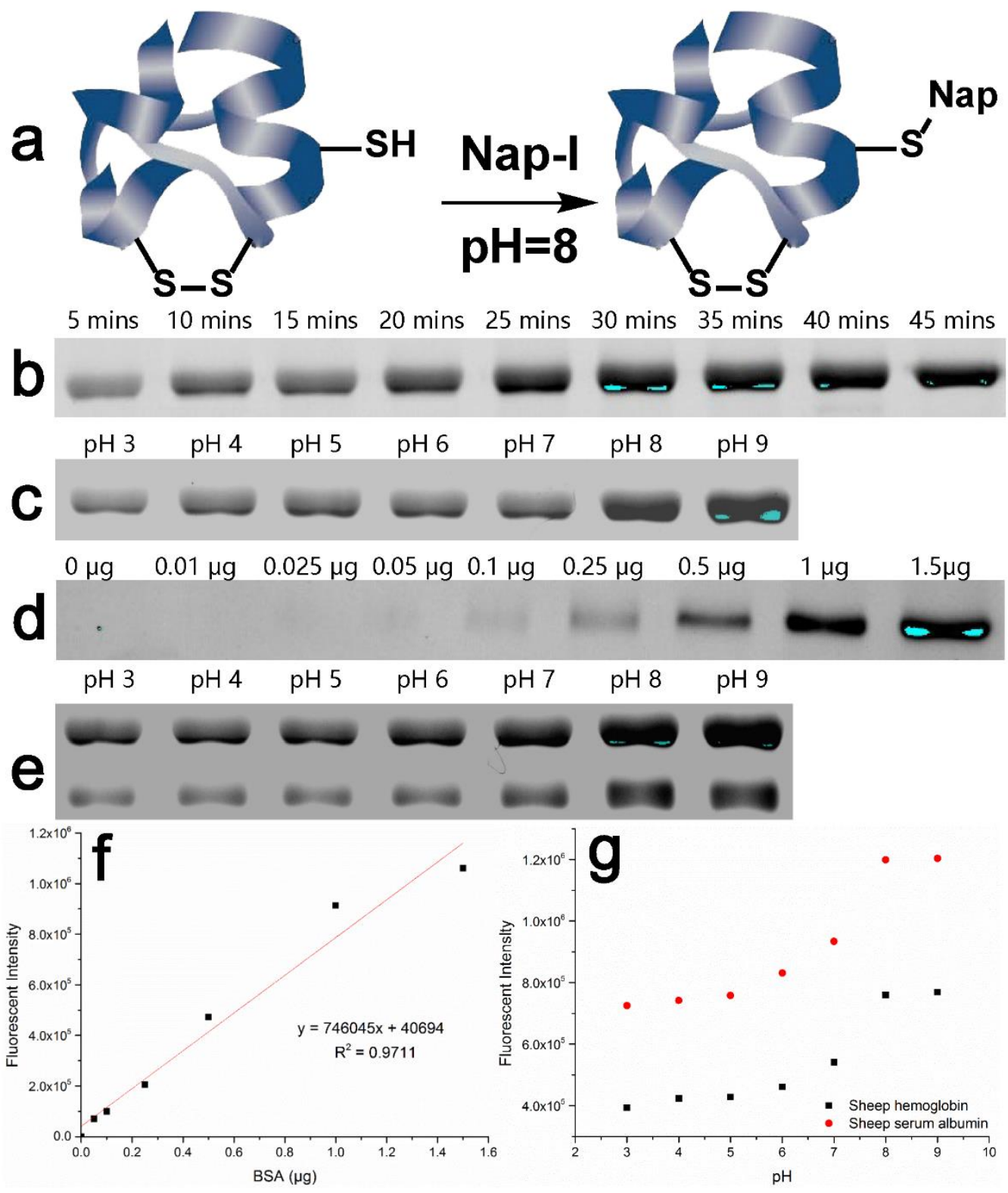

Figure 4. (a) Mechanism of the labeling of Cys-containing proteins by Nap-I; (b) SDS-PAGE fluorescence image of Nap-I-labeled BSA with different labeling times; (c) SDS-PAGE fluorescence image of Nap-I-labeled BSA with different labeling $\mathrm{pH}$; (d) SDS-PAGE fluorescence image of Nap-I-labeled BSA in different quantities; (e) SDS-PAGE fluorescence image of Nap-I-labeled main proteins with different labeling $\mathrm{pH}$; (f) calibration plot of Nap-I fluorescence vs. amount of BSA in the range 0-1.5 $\mu \mathrm{g}$ and linear relationship; (g) comparison of Nap-I-labeled sheep serum albumin and sheep hemoglobin at different pH. Quantity of protein per band except Figure 3d: ca. $1.5 \mu \mathrm{g}$.

\subsection{Determination of the Main Thiol-Containing Proteins in the Serum of Tan Sheep}

Serum $(1 \mu \mathrm{L})$ from the fourth group of Tan sheep was mixed with Nap-I in Tris-HCl buffer of different $\mathrm{pH}(3.0-9.0)$. The labeling was found to be incomplete after a reaction time of $30 \mathrm{~min}$. Both Tan sheep serum albumin $(69.19 \mathrm{kDa})$ and hemoglobin $(64.29 \mathrm{kDa})$ bear active thiol groups, and are the main thiol-containing proteins in Tan sheep serum. The optimal labeling time here was about $1 \mathrm{~h}$ (Figure 4e,g). The increased time requirement may be due to the enzyme activity conditions of different proteins and the matrix effect in the actual sample. However, if the reaction time was too long, the Tan sheep serum protein was labeled abnormally at low $\mathrm{pH}$, and if it was too short, only the bands at $\mathrm{pH} 8.0-9.0$ 
appeared (Figures S11 and S12). It was established that $\mathrm{pH} 8.0$ is optimal for detection; the Tan sheep serum albumin content was $38.82 \mathrm{~g} / \mathrm{L}$ and the hemoglobin content was $24.1 \mathrm{~g} / \mathrm{L}$.

\subsection{Differentiation and Labeling of TXNRD1 and TXNRD2 in Mouse Liver}

There are two main bands in commercially available mouse liver thioredoxin reductase, TXNRD1 (54.8 kDa, from cytoplasm) and TXNRD1 (56.6 kDa, from mitochondria). Although there is no effect on the activity measurement of TXNRD, the two main proteins seem to have a negative effect on quantification. Nicotinamide adenine dinucleotide phosphate (NADPH) can be used to reduce TXNRD, but not other selenoproteins. TXNRD is an NADPH-dependent dimeric selenase containing flavin adenine dinucleotide (FAD) domains. It is a member of the pyridine nucleotide-disulfide oxidoreductase family and forms the thioredoxin (Trx) system together with Trx and NADPH [6-8,17]. However, due to a difference in microenvironments in cells, the enzyme activity conditions of TXNRD1 and TXNRD2 are slightly different. The $\mathrm{pH}$ of the cytoplasm and mitochondria are 7.4 and 8.0, respectively. We specifically reduced TXNRD by NADPH at three different $\mathrm{pH}$ values $(6.5,7.4,8.5)$, and incubated the reduced TXNRD with Nap-I at different $\mathrm{pH}$ values of 3.0-9.0 (Figure 5a-d).

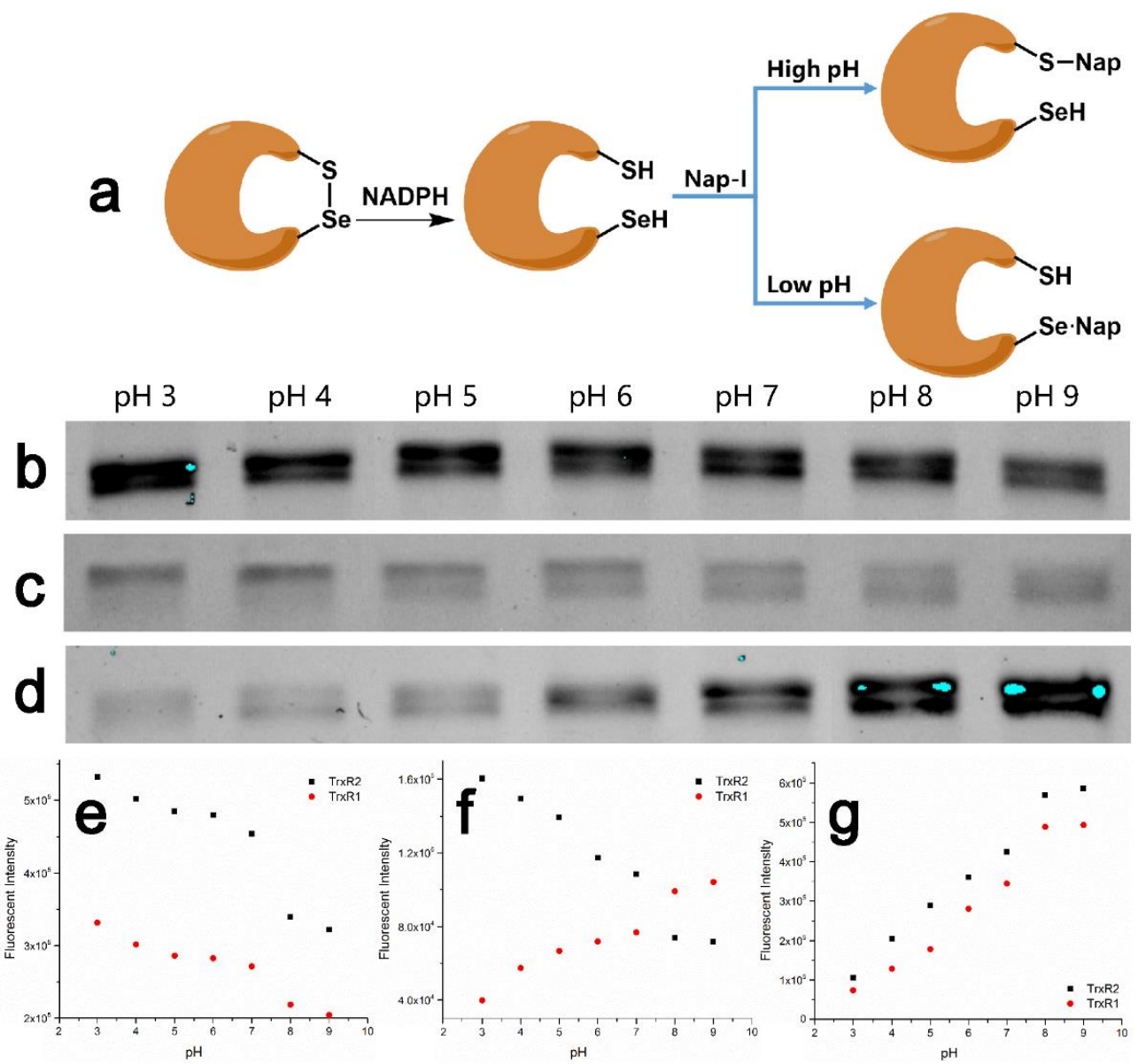

Figure 5. (a) Mechanism of the labeling of TXNRD by Nap-I at different pH; (b) SDS-PAGE fluorescence image of Nap-I-labeled TXNRD from mouse liver reduced by NADPH at $\mathrm{pH} 6.5$ with different labeling $\mathrm{pH}$; (c) SDS-PAGE fluorescence image of Nap-I-labeled TXNRD from mouse liver reduced by NADPH at $\mathrm{pH} 7.4$ with different labeling $\mathrm{pH}$; (d) SDS-PAGE fluorescence image of Nap-I-labeled TXNRD from mouse liver reduced by NADPH at $\mathrm{pH} 8.5$ with different labeling $\mathrm{pH}$; (e) comparison of Nap-I-labeled TXNRDs from mouse liver reduced by NADPH at pH 6.5 at different $\mathrm{pH}$; (f) comparison of Nap-I-labeled TXNRDs from mouse liver reduced by NADPH at pH 7.4 at different $\mathrm{pH}$; (g) comparison of Nap-I-labeled TXNRDs from mouse liver reduced by NADPH at $\mathrm{pH}$ 8.5 at different $\mathrm{pH}$. Quantity of protein per band: ca. $1 \mu \mathrm{g}$. 
TXNRD was reduced by NADPH at pH 6.5 (Figure 5b,e). The exposure of the domain and the selenium-sulfur bond breakage at low $\mathrm{pH}$ make $\mathrm{Sec}$ residues easier to deprotonate and then alkylate by Nap-I, whereas Cys residues are difficult to alkylate at low $\mathrm{pH}$. Whereas the fluorescence intensity at high $\mathrm{pH}$ was relatively weak, it became higher at low $\mathrm{pH}$, and the band resembled the anti-BSA band. The extent of alkylation of Cys residues by Nap-I decreases at low $\mathrm{pH}$, but the alkylation of Sec is favored. Nap-I mainly alkylates Cys at high $\mathrm{pH}$, but because TXNRD is reduced in a weakly acidic environment, the possibility of Cys alkylation is low. The $\mathrm{p} K_{\mathrm{a}}$ of selenol is about 5.2, and TXNRD is more active in the weakly acidic environment of cancer cells, which is related to deprotonation of the Sec residue of TXNRD at low $\mathrm{pH}$. The high activity of TXNRD at low $\mathrm{pH}$ is one of the key factors permitting unlimited expansion of cancer cells [6-8].

When TXNRD was reduced at pH 7.4 (Figure 5c,f), although TXNRD1 is at normal cytoplasmic $\mathrm{pH}$ and the selenium-sulfur bond was broken, the domain may not have been completely exposed. The groups alkylated by Nap-I are mostly Cys residues, which have almost no fluorescence intensity at low $\mathrm{pH}$, so the band for TXNRD1 appeared similar to that for BSA. It is abnormal for TXNRD2 in the environment under pH 7.4, so the TXNRD2 domain has a certain degree of exposure. This is conducive to the alkylation of Sec residues by Nap-I, but the fluorescence intensity of TXNRD2 at low $\mathrm{pH}$ is weaker than that following reduction at $\mathrm{pH}$ 6.5. This implies that not all TXNRD2 domains were exposed and not all Sec residues were deprotonated, so the band for TXNRD2 appears similar to the anti-BSA band. Therefore, although both TXNRD1 and TXNRD2 contain selenium-sulfur bonds and are reduced in the same way, they are still sensitive to different cell microenvironments. This is probably one of the reasons for the loss of mitochondrial function in cancer cells and the relatively active mitochondrial TXNRD2 [50]. ROS are mainly produced and consumed in mitochondria [51-53]. TrxR2 plays a key role when the Trx system consumes ROS, which is an indispensable part of maintaining mitochondrial function [54]. Insomnia disorders are one of the main manifestations of sub-health. Many cancer patients suffer from insomnia disorders in the early stages of onset. Studies have shown that the expression of TrxR2 is significantly higher in patients with insomnia disorders than in those with normal sleep [55]. Therefore, the increased expression of TrxR may be conducive to the early diagnosis of diseases such as cancer.

When TXNRD was reduced at pH 8.5 (Figure 5d,g), although the selenium-sulfur bond may have been broken, since the $\mathrm{pH}$ of the environment was higher than that of the cell microenvironment in which the components reside, the Sec residues were not extensively deprotonated, and thus, were not readily alkylated by Nap-I. At the same time, most of the residues alkylated by Nap-I were Cys residues, so both proteins gave bands resembling those of BSA.

Because the two proteins are in different cell microenvironments, the conditions for activation are slightly different. The environmental $\mathrm{pH}$ when TXNRD is reduced by NADPH is one of the factors that may be influenced by selenol after deprotonation.

Compared with the situation at $\mathrm{pH} 7.4$, when TXNRD2 is activated by NADPH at $\mathrm{pH} 6.5$, the fluorescence intensity is greater and the residues are more easily alkylated by Nap-I, this $\mathrm{pH}$ being lower than that of the microenvironment of TXNRD2 in mitochondria ( $\mathrm{pH}$ 8.0). Therefore, the lower the $\mathrm{pH}$, the more active the TXNRD. However, regardless of the reduction of TXNRD at any of the above $\mathrm{pH}$ values, an excessively long reaction time (such as $1 \mathrm{~h}$ ) will result in similar bands for TXNRD1 and TXNRD2 without a gradient (Figure S13). It is helpful to distinguish TXNRD1 and TXNRD2 at pH 7.4. At the same time, the relative quantification of total TXNRD is desirable at a lower $\mathrm{pH}$.

\subsection{Labeling of TXNRD in Tan Sheep Liver and Muscle}

Next, compared with unreduced TXNRD labeled at pH 8, TXNRDs from Tan sheep liver and muscle were reduced with NADPH at pH 6.5 and labeled with Nap-I at pH 3 (Figure 6a,b). It can be seen that both TXNRD1 (66.97 kDa) and TXNRD2 (50.05 kDa) showed higher fluorescence intensity at low $\mathrm{pH}$ than at high $\mathrm{pH}$, whereas the other bands 
had lower fluorescence intensity at low $\mathrm{pH}$ than at high $\mathrm{pH}$. The total enzyme activity of TXNRD in Tan sheep liver and muscle were calculated by a commercial kit method as $7.55 \mathrm{u} / \mathrm{g}$ and $5.23 \mathrm{u} / \mathrm{g}$, respectively. By comparing the integrated optical densities (IODs), the ratio of the sum of the IODs of the two TXNRD bands in the liver and muscle could be calculated. The ratio of the total TXNRD enzyme activities of the liver and muscle calculated by the commercial kit method was $101.99 \%$, based on Equation (1). The deviation between this method and the kit method was only $1.99 \%$, which shows that the present method has the potential to achieve relative quantification of TXNRD.

$$
\text { The ratio }=\frac{\frac{\text { IOD of TXNRD1 }+ \text { TXNRD2 in liver }}{\text { IOD of TXNRD1 }+ \text { TXNRD2 in muscle }}}{\frac{\text { TXNRD enzyme activity of liver }}{\text { TXNRD enzyme activity of muscle }}} \times 100 \%
$$
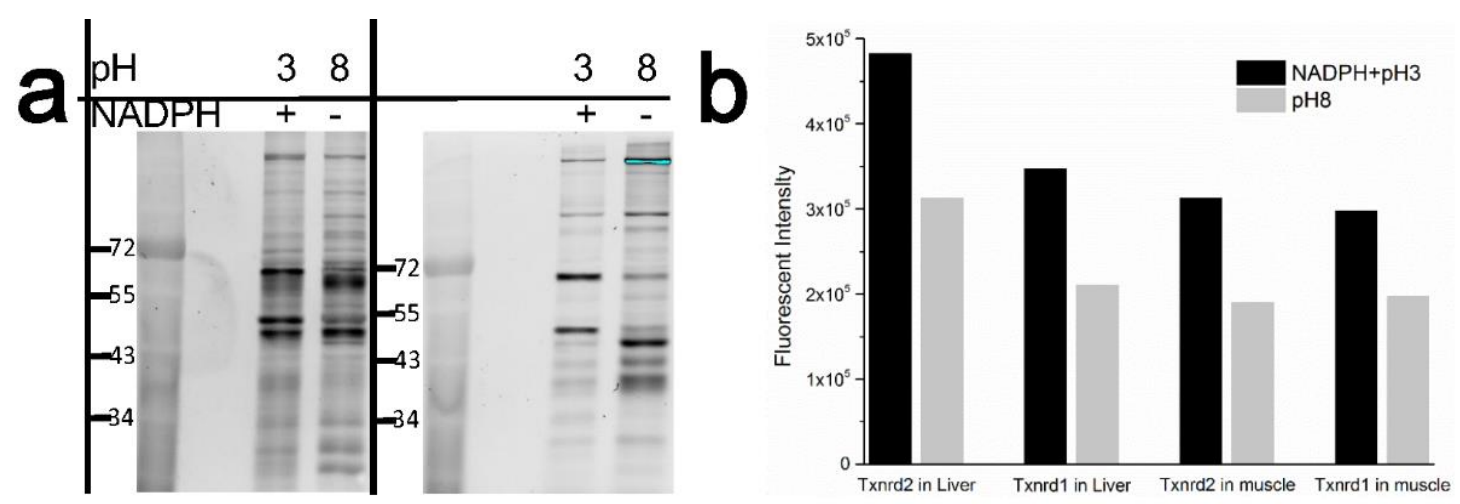

Figure 6. (a) SDS-PAGE fluorescence image of Nap-I-labeled TXNRD from Tan sheep liver and muscle reduced by NADPH at $\mathrm{pH} 6.5$ with labeling at $\mathrm{pH} 3$ and 8; (b) comparison of Nap-I-labeled TXNRDs from Tan sheep liver and muscle, with or without reduction and labeling at low $\mathrm{pH}$. Quantity of protein per band: ca. $1 \mu \mathrm{g}$.

\section{Conclusions}

In conclusion, a novel thiol/selenol-labeling fluorescent probe, Nap-I, has been prepared and evaluated. Probe Nap-I has an excellent signal-to-noise ratio in SDS-PAGE staining applications. By studying the reaction parameters, such as labeling time and $\mathrm{pH}$, the optimal labeling conditions for Cys residues in the protein have been determined, and various proteins containing Cys residues have been labeled. The Sec residues in the protein were labeled under conditions of low $\mathrm{pH}$. The LOD of the Nap-I probe for BSA in SDSPAGE is $37.5 \mathrm{nM}$, and it has been successfully used for the quantification of serum protein and hemoglobin in Tan sheep serum. Based on the probe Nap-I, TXNRD in Tan sheep liver and muscle was labeled at low $\mathrm{pH}$, and TXNRD1 and TXNRD2 could be distinguished. Since the thiol moieties in TXNRD still contribute to the fluorescence intensity, it is difficult to quantify TXNRD only by Nap-I absolutely.

Supplementary Materials: The following are available online at https:/ /www.mdpi.com/article/10 $.3390 /$ bios11050132/s1, Table S1: Fluorescent probes for thiol labeling, Figure S1. ${ }^{1} \mathrm{H}$ and ${ }^{13} \mathrm{C}$ NMR spectra of compound 1, Figure S2. ${ }^{1} \mathrm{H}$ and ${ }^{13} \mathrm{C}$ NMR spectra of compound 2, Figure S3. ${ }^{1} \mathrm{H}$ and ${ }^{13} \mathrm{C}$ NMR spectra of compound 3, Figure S4. ${ }^{1} \mathrm{H}$ and ${ }^{13} \mathrm{C}$ NMR spectra and mass spectrum of Nap-I, Figure S5. Mass spectrum of the alkylation product of Nap-I and Cys, Figure S6. Mass spectrum of the alkylation product of Nap-I and Sec, Figure S7. Quantum yield of Nap-I, Figure S8. Interference experiments: fluorescence responses of $100 \mu \mathrm{m}$ Nap-I in $100 \mathrm{mM}$ Tris- $\mathrm{HCl}$ buffer with 1\% DMSO as co-solvent $\left(\mathrm{V}_{\text {Water }} / \mathrm{V}_{\mathrm{DMSO}}=99: 1\right)$ in the presence of $10 \mathrm{mM}$ of potentially interfering species, namely $\mathrm{NaCl}, \mathrm{KCl}, \mathrm{CaCl}_{2}, \mathrm{MgCl}_{2}, \mathrm{CuSO}_{4}, \mathrm{FeCl}_{3}, \mathrm{ZnCl}_{2}, \mathrm{HCl}, \mathrm{HNO}_{3}, \mathrm{H}_{2} \mathrm{SO}_{4}$, vitamin $\mathrm{C}, \mathrm{H}_{2} \mathrm{O}_{2}, \mathrm{HClO}$, and $\mathrm{NaOH}$, Figure S9. pH stabilities of $100 \mu \mathrm{m}$ Nap-I and $100 \mu \mathrm{m}$ Nap-GSH, Figure S10. Photostability of $100 \mu \mathrm{m}$ Nap-I and $100 \mu \mathrm{m}$ Nap-I, Figure S11. SDS-PAGE fluorescence image of Nap-I-labeled main proteins with different labeling $\mathrm{pH}$ (reaction in $30 \mathrm{~min}$ ), Figure S12. SDS-PAGE fluorescence image 
of Nap-I-labeled main proteins with different labeling $\mathrm{pH}$ (reaction in $1 \mathrm{~h}$ ), Figure S13. SDS-PAGE fluorescence image of Nap-I-labeled TXNRD from mouse liver reduced by NADPH with different labeling $\mathrm{pH}$ (reaction in $1 \mathrm{~h}$ ).

Author Contributions: Y.L.: Writing — original draft; Data curation; Formal analysis; Investigation; Methodology. Y.Y.: Conceptualization; Formal analysis; Project administration. Q.M.: Data curation; Methodology; Software; Validation. J.Z. (Jiawei Zhu): Data curation; Software; Visualization; Validation. X.J.: Animal feeding; Data curation; Methodology. C.T.: Formal analysis; Project administration; Resources. Q.Z.: Resources; Supervision; Funding acquisition. X.F.: Writing-review and editing; Supervision; Methodology; Formal analysis. J.Z. (Junmin Zhang): Supervision; Writing-review and editing; Funding acquisition; Project administration; Resources. All authors have read and agreed to the published version of the manuscript.

Funding: This research was funded by the National Natural Science Foundation of China (31802073), the Special Basic Research Fund for Central Public Research Institutes (2019-YWF-YB-01, Y2020PT19), the Chinese Academy of Agricultural Science and Technology Innovation Project (ASTIP-IAS-12), the Special R\&D Program Project of the Chinese Academy of Se-enriched Industry (2019QCY3.2, 2019QCY-3.3), and the Key Laboratory of Se-Enriched Products Development and Quality Control, Ministry of Agriculture and Rural Affairs/National-Local Joint Engineering Laboratory of Se-Enriched Food Development (Se-2018HZ01).

Institutional Review Board Statement: The study was conducted according to the guidelines of the Declaration of Helsinki, and approved by the Ethics Committee of the Institute of Animal Science, Chinese Academy of Agricultural Sciences (IAS2019-47).

Informed Consent Statement: Not applicable.

Conflicts of Interest: The authors declare no conflict of interest.

\section{References}

1. Jacob, C.; Giles, G.I.; Giles, N.M.; Sies, H. Sulfur and selenium: The role of oxidation state in protein structure and function. Angew. Chem. Int. Ed. 2003, 42, 4742-4758. [CrossRef]

2. Liu, Y.; Yu, Y.; Zhao, Q.; Tang, C.; Zhang, H.; Qin, Y.; Feng, X.; Zhang, J. Fluorescent probes based on nucleophilic aromatic substitution reactions for reactive sulfur and selenium species: Recent progress, applications, and design strategies. Coord. Chem. Rev. 2021, 427, 213601-213622. [CrossRef]

3. Yin, K.; Yu, F.; Zhang, W.; Chen, L. A near-infrared ratiometric fluorescent probe for cysteine detection over glutathione indicating mitochondrial oxidative stress in vivo. Biosens. Bioelectron. 2015, 74, 156-164. [CrossRef]

4. Mousa, R.; Notis Dardashti, R.; Metanis, N. Selenium and Selenocysteine in Protein Chemistry. Angew. Chem. Int. Ed. 2017, 56, 15818-15827. [CrossRef]

5. Rayman, M.P. Selenium and human health. Lancet 2012, 379, 1256-1268. [CrossRef]

6. Zhang, B.; Liu, Y.; Li, X.; Xu, J.; Fang, J. Small Molecules to Target the Selenoprotein Thioredoxin Reductase. Chem-Asian J. 2018, 13, 3593-3600. [CrossRef] [PubMed]

7. Zhang, B.; Zhang, J.; Peng, S.; Liu, R.; Li, X.; Hou, Y.; Han, X.; Fang, J. Thioredoxin reductase inhibitors: A patent review. Expert Opin. Ther. Pat. 2017, 27, 547-556. [CrossRef]

8. Zhang, J.; Li, X.; Han, X.; Liu, R.; Fang, J. Targeting the Thioredoxin System for Cancer Therapy. Trends Pharmacol. Sci. 2017, 38, 794-808. [CrossRef] [PubMed]

9. Liu, Y.; Feng, X.; Yu, Y.; Zhao, Q.; Tang, C.; Zhang, J. A review of bioselenol-specific fluorescent probes: Synthesis, properties, and imaging applications. Anal. Chim. Acta 2020, 1110, 141-150. [CrossRef]

10. Bak, D.W.; Gao, J.; Wang, C.; Weerapana, E. A Quantitative Chemoproteomic Platform to Monitor Selenocysteine Reactivity within a Complex Proteome. Cell Chem. Biol. 2018, 25, 1157-1167. [CrossRef] [PubMed]

11. Maeda, H.; Katayama, K.; Matsuno, H.; Uno, T. 3'-(2,4-Dinitrobenzenesulfonyl)-2' $7^{\prime}$-dimethylfluorescein as a fluorescent probe for selenols. Angew. Chem. Int. Ed. 2006, 45, 1810-1813. [CrossRef]

12. Han, X.; Wang, R.; Song, X.; Yu, F.; Chen, L. Evaluation Selenocysteine Protective Effect in Carbon Disulfide Induced Hepatitis with a Mitochondrial Targeting Ratiometric Near-Infrared Fluorescent Probe. Anal. Chem. 2018, 90, 8108-8115. [CrossRef]

13. Zhang, B.; Ge, C.; Yao, J.; Liu, Y.; Xie, H.; Fang, J. Selective selenol fluorescent probes: Design, synthesis, structural determinants, and biological applications. J. Am. Chem. Soc. 2015, 137, 757-769. [CrossRef]

14. Zhang, S.; Wang, Q.; Liu, X.; Zhang, J.; Yang, X.F.; Li, Z.; Li, H. Sensitive and Selective Fluorescent Probe for Selenol in Living Cells Designed via a p Ka Shift Strategy. Anal. Chem. 2018, 90, 4119-4125. [CrossRef]

15. Cheng, D.; Pan, Y.; Yin, B.C.; Yuan, L.; Zhang, X.B. A new fluorescent probe with ultralow background fluorescence for imaging of endogenous cellular selenol under oxidative stress. Chin. Chem. Lett. 2017, 28, 1987-1990. [CrossRef] 
16. Kong, F.; Zhao, Y.; Liang, Z.; Liu, X.; Pan, X.; Luan, D.; Xu, K.; Tang, B. Highly Selective Fluorescent Probe for Imaging H2Se in Living Cells and in Vivo Based on the Disulfide Bond. Anal. Chem. 2017, 89, 688-693. [CrossRef] [PubMed]

17. Zhang, L.; Duan, D.; Liu, Y.; Ge, C.; Cui, X.; Sun, J.; Fang, J. Highly selective off-on fluorescent probe for imaging thioredoxin reductase in living cells. J. Am. Chem. Soc. 2014, 136, 226-233. [CrossRef] [PubMed]

18. Li, X.; Zhang, B.; Yan, C.; Li, J.; Wang, S.; Wei, X.; Jiang, X.; Zhou, P.; Fang, J. A fast and specific fluorescent probe for thioredoxin reductase that works via disulphide bond cleavage. Nat. Commun. 2019, 10, 2745. [CrossRef] [PubMed]

19. Hu, B.; Cheng, R.; Liu, X.; Pan, X.; Kong, F.; Gao, W.; Xu, K.; Tang, B. A nanosensor for in vivo selenol imaging based on the formation of Au-Se bonds. Biomaterials 2016, 92, 81-89. [CrossRef]

20. Liu, X.; Hu, B.; Cheng, R.; Kong, F.; Pan, X.; Xu, K.; Tang, B. Simultaneous fluorescence imaging of selenol and hydrogen peroxide under normoxia and hypoxia in HepG2 cells and in vivo. Chem. Commun. 2016, 52, 6693-6696. [CrossRef]

21. Liang, B.; Shao, W.; Zhu, C.; Wen, G.; Yue, X.; Wang, R.; Quan, J.; Du, J.; Bu, X. Mitochondria-Targeted Approach: Remarkably Enhanced Cellular Bioactivities of TPP2a as Selective Inhibitor and Probe toward TrxR. ACS Chem. Biol. 2016, 11, 425-434. [CrossRef]

22. Huang, L.; Chen, Y.; Liang, B.; Xing, B.; Wen, G.; Wang, S.; Yue, X.; Zhu, C.; Du, J.; Bu, X. A furanyl acryl conjugated coumarin as an efficient inhibitor and a highly selective off-on fluorescent probe for covalent labelling of thioredoxin reductase. Chem. Commun. 2014, 50, 6987-6990. [CrossRef]

23. Tian, Y.; Xin, F.Y.; Gao, C.C.; Jing, J.; Zhang, X.L. Ratiometric fluorescence imaging of endogenous selenocysteine in cancer cell matrix. J. Mater. Chem. B 2017, 5, 6890-6896. [CrossRef] [PubMed]

24. Kong, F.; Hu, B.; Gao, Y.; Xu, K.; Pan, X.; Huang, F.; Zheng, Q.; Chen, H.; Tang, B. Fluorescence imaging of selenol in HepG2 cell apoptosis induced by Na2SeO3. Chem. Commun. 2015, 51, 3102-3105. [CrossRef]

25. Kong, F.; Ge, L.; Pan, X.; Xu, K.; Liu, X.; Tang, B. A highly selective near-infrared fluorescent probe for imaging H2Se in living cells and in vivo. Chem. Sci. 2016, 7, 1051-1056. [CrossRef] [PubMed]

26. Tian, Y.; Xin, F.; Jing, J.; Zhang, X. Fluorescence imaging of lysosomal hydrogen selenide under oxygen-controlled conditions. J. Mater. Chem. B 2019, 7, 2829-2834. [CrossRef]

27. Pan, X.; Song, X.; Wang, C.; Cheng, T.; Luan, D.; Xu, K.; Tang, B. H2Se Induces Reductive Stress in HepG2 Cells and Activates Cell Autophagy by Regulating the Redox of HMGB1 Protein under Hypoxia. Theranostics 2019, 9, 1794-1808. [CrossRef] [PubMed]

28. Manjare, S.T.; Kim, Y.; Churchill, D.G. Selenium- and tellurium-containing fluorescent molecular probes for the detection of biologically important analytes. Acc. Chem. Res. 2014, 47, 2985-2998. [CrossRef]

29. Wu, D.; Chen, L.; Kwon, N.; Yoon, J. Fluorescent Probes Containing Selenium as a Guest or Host. Chem 2016, 1, 674-698. [CrossRef]

30. Ismail, I.; Wang, D.; Wang, Z.; Wang, D.; Zhang, C.; Yi, L.; Xi, Z. A julolidine-fused coumarin-NBD dyad for highly selective and sensitive detection of H2S in biological samples. Dyes Pigments 2019, 163, 700-706. [CrossRef]

31. Kang, J.; Huo, F.; Yao, Y.; Yin, C. A high signal-to-background ratio H2S-specific fluorescent probe based on nucleophilic substitution and its bioimaging for generation H2S induced by $\mathrm{Ca}^{2+}$ in vivo. Dyes Pigment. 2019, 171, 107755-107760. [CrossRef]

32. Zhai, L.; Shi, Z.; Tu, Y.; Pu, S. A dual emission fluorescent probe enables simultaneous detection and discrimination of Cys/Hcy and GSH and its application in cell imaging. Dyes Pigment. 2019, 165, 164-171. [CrossRef]

33. Maeda, H.; Matsuno, H.; Ushida, M.; Katayama, K.; Saeki, K.; Itoh, N. 2,4-Dinitrobenzenesulfonyl fluoresceins as fluorescent alternatives to Ellman's reagent in thiol-quantification enzyme assays. Angew. Chem. Int. Ed. 2005, 44, 2922-2925. [CrossRef] [PubMed]

34. Sun, J.; Zhang, L.; Zhang, X.; Hu, Y.; Ge, C.; Fang, J. An ultrafast turn-on thiol probe for protein labeling and bioimaging. Analyst 2016, 141, 2009-2015. [CrossRef] [PubMed]

35. Chen, M.Z.; Moily, N.S.; Bridgford, J.L.; Wood, R.J.; Radwan, M.; Smith, T.A.; Song, Z.; Tang, B.Z.; Tilley, L.; Xu, X.; et al. A thiol probe for measuring unfolded protein load and proteostasis in cells. Nat. Commun. 2017, 8, 474. [CrossRef]

36. Li, X.; Feng, Q.; Qu, L.; Zhao, T.; Li, X.; Bai, T.; Sun, S.; Wu, S.; Zhang, Y.; Li, J. A water-soluble and incubate-free fluorescent environment-sensitive probe for ultrafast visualization of protein thiols within living cells. Anal. Chim. Acta 2020, 1126, 72-81. [CrossRef]

37. Yu, Y.; Li, J.; Chen, S.; Hong, Y.; Ng, K.M.; Luo, K.Q.; Tang, B.Z. Thiol-reactive molecule with dual-emission-enhancement property for specific prestaining of cysteine containing proteins in SDS-PAGE. ACS Appl. Mater. Interfaces 2013, 5, 4613-4616. [CrossRef]

38. Zhang, L.Y.; Tu, F.Q.; Guo, X.F.; Wang, H.; Wang, P.; Zhang, H.S. A new BODIPY-based long-wavelength fluorescent probe for chromatographic analysis of low-molecular-weight thiols. Anal. Bioanal. Chem. 2014, 406, 6723-6733. [CrossRef]

39. Huang, K.J.; Han, C.H.; Han, C.Q.; Li, J.; Wu, Z.W.; Liu, Y.M. Determination of thiol compounds by solid-phase extraction using multi-walled carbon nanotubes as adsorbent coupled with high-performance liquid chromatography-fluorescence detection. Microchim. Acta 2011, 174, 421-427. [CrossRef]

40. Guo, L.; Yang, W.; Huang, Q.; Qiang, J.; Hart, J.R.; Wang, W.; Hu, J.; Zhu, J.; Liu, N.; Zhang, Y. Selenocysteine-Specific Mass Spectrometry Reveals Tissue-Distinct Selenoproteomes and Candidate Selenoproteins. Cell Chem. Biol. 2018, 25, 1380-1388. [CrossRef]

41. Jedrychowski, M.P.; Lu, G.Z.; Szpyt, J.; Mariotti, M.; Garrity, R.; Paulo, J.A.; Schweppe, D.K.; Laznik-Bogoslavski, D.; Kazak, L.; Murphy, M.P.; et al. Facultative protein selenation regulates redox sensitivity, adipose tissue thermogenesis, and obesity. Proc. Natl. Acad. Sci. USA 2020, 117, 10789-10796. [CrossRef] [PubMed] 
42. Zhu, X.; Li, Y.; Zan, W.; Zhang, J.; Chen, Z.; Liu, X.; Qi, F.; Yao, X.; Zhang, X.; Zhang, H. A two-photon off-on fluorescence probe for imaging thiols in live cells and tissues. Photochem. Photobiol. Sci. 2016, 15, 412-419. [CrossRef]

43. Liu, T.; Xu, Z.; Spring, D.R.; Cui, J. A Lysosome-Targetable Fluorescent Probe for Imaging Hydrogen Sulfide in Living Cells. Org. Lett. 2013, 15, 2310-2313. [CrossRef]

44. Yang, Y.; Tang, C.; Gu, X. Synthesis of Near-Infrared Fluorescence Probe Reagents for Site-Specific Labeling of Proteins. Chem. Bull. 2016, 79, 856-875.

45. Allen, C.D.; Chen, M.Y.; Trick, A.Y.; Le, D.T.; Ferguson, A.L.; Link, A.J. Thermal Unthreading of the Lasso Peptides Astexin-2 and Astexin-3. ACS Chem. Biol. 2016, 11, 3043-3051. [CrossRef] [PubMed]

46. Yu, C.; Tang, J.; Loredo, A.; Chen, Y.; Jung, S.Y.; Jain, A.; Gordon, A.; Xiao, H. Proximity-Induced Site-Specific Antibody Conjugation. Bioconjug. Chem. 2018, 29, 3522-3526. [CrossRef] [PubMed]

47. Barksdale, A.D.; Rosenberg, A. Thermodynamic characterization of subunit association in liganded ferrohemoglobin. The temperature $\mathrm{pH}$, and anion dependence of the carboxyhemoglobin A dimer-tetramer equilibrium. J. Biol. Chem. 1978, 253, 4881-4885. [CrossRef]

48. Nagel, R.L.; Gibson, Q.H. The binding of hemoglobin to haptoglobin and its relation to subunit dissociation of hemoglobin. J. Biol. Chem. 1971, 246, 69-73. [CrossRef]

49. Zhang, L.; Levy, A.; Rifkind, J.M. Autoxidation of hemoglobin enhanced by dissociation into dimers. J. Biol. Chem. 1991, 266, 24698-24701. [CrossRef]

50. Gencheva, R.; Cheng, Q.; Arner, E.S.J. Efficient selenocysteine-dependent reduction of toxoflavin by mammalian thioredoxin reductase. Biochim. Biophys. Acta Gen. Subj. 2018, 1862, 2511-2517. [CrossRef]

51. Loeb, L.A.; Wallace, D.C.; Martin, G.M. The mitochondrial theory of aging and its relationship to reactive oxygen species damage and somatic mtDNA mutations. Proc. Natl. Acad. Sci. USA 2005, 102, 18769-18770. [CrossRef] [PubMed]

52. Van Eyken, E.; Van Camp, G.; Van Laer, L. The complexity of age-related hearing impairment: Contributing environmental and genetic factors. Audiol. Neurootol. 2007, 12, 345-358. [CrossRef] [PubMed]

53. Wallace, D.C. A mitochondrial paradigm of metabolic and degenerative diseases, aging, and cancer: A dawn for evolutionary medicine. Annu. Rev. Genet. 2005, 39, 359-407. [CrossRef] [PubMed]

54. Stanley, B.A.; Shi, S.; Sivakumaran, V.; Watson, W.; Aon, M.; Paolocci, N. The Thioredoxin 2 system Controls H2O2 Emission Flux from Mitochondria. Biophys. J. 2011, 100, 458. [CrossRef]

55. Yang, J.-H. Levels of Serum Thioredoxin System in Patients with Insomnia Disorder and Healthy Control: A Case-Control Study; Jinan University: Guangzhou, China, 2016. 